\title{
Causes, Dimensions and Organizational Consequences of Mobbing: An Empirical Study
}

\author{
Nuray YAPICI AKAR ${ }^{1}$, Nilgün ANAFARTA², Fulya SARVAN ${ }^{3}$
}

\begin{abstract}
This paper aims to explore the relations between the perceived causes and dimensions of mobbing and two important organizational consequences, job satisfaction and turnover intention. The study employed survey design to collect data from 248 white collar employees working for SME's operating in the agriculture industry in Antalya, Turkey. Leymann Inventory of Psychological Terrorization was used for data collection. More than half of the respondents had been subjected to some kind of mobbing during the previous year, for at least six months duration, most frequently from peers and generally due to organizational factors. Victims had lower levels of job satisfaction and most of them intended to leave the job.
\end{abstract}

Key Words: Mobbing, perceived causes of mobbing, job satisfaction, turnover intention, agriculture sector

\section{INTRODUCTION}

Mobbing is an organizational phenomenon that has attracted the attention of organizational psychologists as early as 1980 's. Since then this phenomenon was explored from many perspectives, providing a portrayal of the dimensions of mobbing behavior, its actors, antecedents and consequences. The correspondence between many of these variables have been subject to various studies, but some relationships remained underexplored. This studyaims to fill some of these gaps by exploring the relations between the perceived causes and dimensions of mobbing and their impact on job satisfaction and turnover intention of white collar employees in the agriculture SME's in Antalya, Turkey.

Dealing with mobbing in work life in Turkey poses difficulties, because the provisions in the Labour Law and other regulations regarding psychological assaults in organizations remains inadequate compared to those of other European countries. It is therefore very important to explore this phenomenon from all perspectives to build up a proper understanding and to increase the awareness of practitioners and policy makers related to this issue. Thus, the present study will investigate the relationships between perceived causes, dimensions and some important consequences of mobbing in the agricultural SME's in Antalya, Turkey. The findings of the study will be compared with similar studies from Europe to provide a discussion on the relavance of some contextual factors, like culture, legal system and organizational features, on the findings of the study. The authors hope to contribute to the knowledge about the mobbing phenomenon by shedding light on the relationships between perceived causes and dimensions of mobbing and two important organizational consequences, job satisfaction and turnover intention, which have not been investigated in the same study before. The agricultural context of the study, which has been studied very seldom before, is hoped to increase its value.

\section{CONCEPTUAL BACKGROUND}

Studies all over the world indicate that mobbing is a globally pervasive issue, emanating from the increasingly competitive and stressful organizational life. A study conducted in 15 member states of the European Union in 1996 on a sample of 15.800 respondents demonstrated that $4 \%$ were subject to physical violence, $2 \%$ to sexual harassment, and $8 \%$ to mobbing (Chappel and Di Martino, 1998: 9). With the raising awareness about this phenomenon, organizational studies exploring this issue provided evidence to the fact that mobbing has the potential to reduce job satisfaction and raise employee turnover (Morrison and Nolan, 2007:

\footnotetext{
${ }^{1}$ Research Assistant, Akdeniz University, Faculty of Economics and Administrative Sciences, Department of Business Administration, nurayyapici@akdeniz.edu.tr

${ }^{2}$ Assoc. Prof. Dr., Akdeniz University, Faculty of Economics and Administrative Sciences, Department of Business Administration, anafarta@akdeniz.edu.tr 179

${ }^{3}$ Prof. Dr., Akdeniz University, Faculty of Economics and Administrative Sciences, Department of Business Administration, fulyas@akdeniz.edu.tr
} 
206). There is no doubt that these organizational results represent undesirable consequences for managers and/or organizations seeking excellence and competitive power. The severity of the issue is understood better when the frequency of mobbing in different countries is examined. For example, a study conducted in Sweden on a representative sample of the population demonstrated that 3.5\% of the work force was exposed to mobbing (Leymann, 1996: 175). This proportion indicates that one out of every four employee was confronted with the risk of being subjected to mobbing for at least 6 months on the average of thirty years.

Recent studies about mobbing in Turkey have also indicated considerable rates of prevalence in various types of organizations (Bilgel et al., 2006; Yıldırım et al., 2007). The study by Çobanoğlu (2005: 13) came up with the finding that in Turkey the proportion of mobbing victims exceeds $20 \%$. The survey conducted on employees from different sectors by yenibiris.com, one of the HRM internet portals in Turkey, indicated that the second important factor that led employees to psychological depression was the mobbing exercised by their peers or supervisors (Hurriyet IK, 29.03.2009). Another survey demonstrated that the second most important reason for leaving job was being victimized to mobbing (Hurriyet IK, 05.04.2009).

\subsection{The Mobbing Phenomenon}

The first studies on mobbing started early 1980's by Scandinavian psychologists on a psycho-social dimension as a factor of welfare and security in the workplace (Lee, 2000; Moayed et al., 2006). Business psychologist and medical scientist Heinz Leymann (1993) was the first to introduce the concept in Germany after 10 years it was introduced in Scandinavia (Zapf et al., 1996: 215), and his work gained prominence especially due to the Inventory of Psychological Terrorization that he developed. Leymann (1996: 165) used the word mobbing from an organizational psychology viewpoint, to mean "harassing, ganging up on someone, or psychologically terrorizing others at work". Zapf (1999: 70) defined mobbing as psychological aggression that often involves a group of mobbers rather than a single person, and is generally exercised by a superior. He also argued that the mobber is able to mobilize other people against the victim, and in case the upper management disregards the situation the issue may gain organizational dimensions. It is ordinarily accepted that mobbing is a long term, recurring, persistent and deliberate behavior targeted to a specific person (Einarsen, 1999; Leymann, 1996). Three groups of people are involved in the mobbing process: Those who exercise mobbing, the perpetrators, those who are exposed to mobbing, the victims, and those who witness the process, the bystanders. These three groups interact with each other while playing their roles (Tınaz, 2006: 57). The perpetrator, who may exercise mobbing for reasons such as positional concern, stereotypes, personality differences, envy or personal rivalry, can be a superior, a peer or a subordinate in the organizational hierarchy (Salin, 2003; Tutar, 2004). In this context, the following research question was designed:

Who are the perpetrators usually in regards to their organizational status such as superiors, peers and subordinates?

\subsection{Relationships Between Causes and Dimensions of Mobbing}

The authors of the present study handled the interrelated factors most often cited as causes of mobbing in literature in three groups:

Organizational Causes: Imbalances in delegation of authority, excessive work load and/ or stress, weaknesses or uncertainties related with management, gaps in communication networks, monotony of work, leadership style, organization culture or organizational change have been cited as the organizational sources of mobbing (Duffy and Sperry, 2007; Vandekerckhove and Commers, 2003).

Social Causes: Hostility, envy, excessive competition and ambition, group pressure, disposition to humiliate or scapegoat someone, social changes and cultural traits have been indicated as social causes of mobbing (Bilgel et al., 2006; Kök, 2006; Rayner and Hoel, 1997).

Personal Causes (Factors Related with Perpetrators and Victims): Personality, psychological state, personality disorders, individual traits, social skills, demographic traits and perceptual differences have been presented as the personal causes that may trigger mobbing (Duffy and Sperry, 2007; Einarsen, 1999; Leymann, 1993).

The literature on mobbing does not provide detailed findings pertaining to the relationship between different causes and dimensions of mobbing. However it would be of interest for the practitioners and policy makers to know which type of cause is likely to trigger what type of mobbing behavior in which group of employee (superiors, peers and subordinates). In order to explore these under examined relationships, the first hypothesis of the study was formulated as:

$H_{1}$ : There is a relationship between the perceived 
causes and dimensions of mobbing exercised by superiors, peers and subordinates.

\subsection{Organizational Consequences of Mobbing}

Mobbing gives rise to many negative social, psychological and economic effects on organizations and society. It weakens the capability of the organization to maintain its performance level, and causes persistent organizational problems that cannot be resolved (Jacobshagen, 2004; Tınaz, 2006). Loss of a healthy and humane work environment, dominance of an intense climate in the workplace and lessening of job satisfaction eventually lead to organizational entropy (Leymann, 1996; Quine, 2001). Moreover, if mobbing gains the character of an organizational policy, it may recur for another victim after a while (Clarke, 2002: 72). Studies have shown that the damaged organizational culture no longer provides motivation to the personnel, gives rise to an alienation process, leads to job unsatisfaction and turnover intention, destroys organizational trust (Einarsen, 2000; Zapf, 1999), reduces commitment to work and organization (Schat and Kelloway, 2000: 386), blocks institutionalization (Baykal, 2005: $3)$, causes loss of reputation and customer, and weakens competitive power. With the accumulation of these negative effects, the number of unhappy and unhealthy members in the society increases, giving rise to serious amounts in health expenditures of the public budget (Davenport et al., 2003: 146-148). This present study focuses on the relationship of mobbing with job satisfaction and turnover intention, the organizational damages of which can be rather persistent in the long run.

\subsection{Relationship between Mobbing and Job Satisfaction}

Job satisfaction is conceptualized as a function of the correspondence between organizational outcomes and values (Greenhaus et al., 2006: 72). Job satisfaction as an expression of the contentment of employees with their job, requires gratification with the economic, physical, social and psychological aspects of work. In the study by Einarsen et al. (1994: 382) it was noted that the quality of interpersonal communication in theworkplace is importantin regard to the work stress and job satisfaction perceptions of employees. Vartia (1996: 211) found correspondence between good interpersonal relations and job satisfaction. In other empirical studies dealing with the relations between mobbing and job satisfaction, it was generally concluded that job satisfaction of victims exposed to mobbing diminished (Bilgel et al.,
2006; Moayed et al., 2006).

Depending on these findings the below listed hypotheses were driven to demonstrate the correspondence between mobbing and job satisfaction.

$H_{2 a}$ : There is a negative relationship between the dimensions of mobbing exercised by superiors and job satisfaction.

$H_{26}$ : There is a negative relationship between the dimensions of mobbing exercised by peers and job satisfaction.

$H_{2 c}:$ There is a negative relationship between the dimensions of mobbing exercised by subordinates and job satisfaction.

\subsection{Relationship between Mobbing and Turnover Intention}

Turnover intention refers to the probability of an employee to quit work and leave the organization with his/her own will (Kuvaas, 2006: 509). As the turnover intention of the employee intensifies, there is an increase in the turnover rate and absenteeism. Such withdrawal behavior involves psychological, sociological and economic consequences that render it essential to analyse the development of the turnover intention and predict employee turnover. Djurkovic et al. (2004: 469) found positive correlation between mobbing and turnover intention. Other empirical studies confirmed that mobbing gave rise to increased turnover intention of the victims, and with intensification of mobbing and extension of its duration, the turnover intention resulted in quitting job (Einarsen, 2000; Salin, 2003; Thomas, 2005). The below listed hypotheses were drawn to test the relation between mobbing and turnover intention:

$H_{3 a}$ : There is a positive relationship between the dimensions of mobbing exercised by superiors and turnover intention.

$H_{3 b}$ : There is a positive relationship between the dimensions of mobbing exercised by peers and turnover intention.

$H_{3 c}$ : There is a positive relationship between the dimensions of mobbing exercised by subordinates and turnover intention.

\subsection{Relationship between Job Satisfaction and Turnover Intention}

Literature review revealed a number of studies exploring the relations between job satisfaction and turnover intention, generally concluding that low job satisfaction results in turnover intention. When this 
intention reaches a certain level, the employee starts looking for another job. The decision to leave the job or stay and continue depends on the comparison of the current job with alternative job opportunities. The actual turnover will depend on the results of this comparison (Çekmecelioğlu, 2005; Lee et al., 2004). Seifert and Umbach (2008: 357) noted that job satisfaction is an important indicator of the decision to stay in academic career or leave the job. The study conducted by Çekmecelioğlu (2005: 33) on four paint companies in the Gebze-Dil Ovası region found negative relationship between job satisfaction and turnover intention. Findings of Mor Barak et al. (2001: 653) in the areas of nursing, manufacturing, IT and armed forces confirmed that low job satisfaction constituted one of the main reasons for the formation of turnover intention. Moreover it was demonstrated that technicians working in the private sector displayed higher job satisfaction, organizational commitment and intention to stay in their current jobs, compared with their public counterparts. The hypothesis below was formulated to test the relation between job satisfaction and turnover intention in this study.

$H_{4}$ : There is a negative relationship between job satisfaction and turnover intention.

\section{THE RESEARCH MODEL}

The model of the research was based on the findings of the previous research on mobbing. According to the model causes of mobbing are related with the dimensions of mobbing in the organization, which are in turn related with job satisfaction and turnover intention, which also have a relation with each other. The hypotheses formulated above constituted the main assumptions to be tested. The survey of this model was designed to find out the type, causes, frequency and perpetrators of mobbing among the employees of SME's in the agriculture sector of Antalya, Turkey. The data collected was used to test the existence of relationships between the causes and dimensions of mobbing, and between mobbing and job satisfaction and turnover intention.

\section{METHODOLOGY}

\subsection{Sample and Procedure}

The research of this study was conducted on employees working for seven SME's operating in the agriculture industry of Antalya, one of the leading tourism and agriculture centers in Turkey (www. antalya.com, accessed 11.08.2009). These seven firms were selected from a list of agriculture companies registered to the Antalya Chamber of Commerce and Industry-ACCl and employing more than 50 people. These seven firms were the ones that agreed to cooperate for this survey. The questionnaires used for data collection were distributed to the full-time employees of these firms by the personnel or human resources or administrative-financial managers, under the supervision of the researchers. Only white collar personnel with a minimum education level of high school (11 years schooling) or above were included in the respondent group, in order to ensure correct interpretation of the items in the questionnaire and a high response rate. Out of the 412 questionnaires handed out 248 were returned, achieving a response rate of approximately $60 \%$.

\subsection{Measures}

The questionnaire designed as data collection tool consisted of three parts. The first part contained items related with perceived causes of mobbing, the second contained scales for measuring mobbing, job satisfaction, and turnover intention, and the third part consisted of demographic questions. The scales employed are explained below.

Perceived Causes of Mobbing: The authors made use of the relevant literature (Einarsen, 2000; Leymann, 1996; Tutar, 2004; Zapf, 1999) to explore the perceived causes of mobbing. The items included in the scale were the ones most often cited as causes of mobbing. The respondents were asked to sign five items that they found important as the causes of mobbing.

Mobbing: Leymann Inventory of Psychological Terrorization-LIPT (www.leymann.se/deutsch, accessed 09.07.2007) was used to measure the prevalence of mobbing, and to determine by whom (supervisors, peers or subordinates) it was exercised. This measurement device is a five-point Likert type questionnaire, consisting of forty five items and ranging from $1=$ never to $5=$ always. It was translated from German to Turkish and the original version was preserved with only small modifications. The respondents were asked to consider the last one year and at least six months period in evaluating these items while keeping in mind their superiors, peers and subordinates.

The original inventory is based on five dimensions, including mobbing directed at preventing the person from communicating with others and asserting oneself, mobbing directed at social relationships, mobbing directed at the reputation of the individual, mobbing directed at the quality of life and career 
status of the person, and mobbing directed at the health of the person. Explanatory factor analysis was used for dimension analysis of this inventory. The analysis of the data concerning mobbing exercised by superiors and peers resulted in five dimensions. The KMO (Kaiser-Meyer-Olkin) value for mobbing from superiors was 0.91 and for mobbing from peers 0.94 . The significance of Bartlett's Test of Sphericity was calculated as $p=0.000$ for both data. Total variance explanation rate of these five factors was $64.22 \%$ for mobbing from the superiors, $70.36 \%$ for mobbing from the peers. Factor loads were above 0.40 . The distribution found was in conformance with the five dimensions of Leymann (1996). The only different dimension that was found in this study was the fifth factor which Leymann originally called "mobbing directed at the health of the person", that is something generally unspoken in the Turkish culture, because it refers to physical aggression and sexual harassment. For this reason, the fifth dimension was formulated as "mobbing through rumours, criticism, rejection and unfair evaluations". As a matter of fact Hubert and Veldhoven (2001) had also found in their study that factoring of mobbing differed from industry to industry.

The factor analysis administered on the mobbing data exercised by subordinates resulted in a factor structure different from the theory. When items with factor loading below 0.40 were eliminated a two factor structure was obtained. These factors were named as "mobbing directed at work", and "mobbing directed at personality". KMO value was 0.95 and significance of Bartlett Spherecity test $p=0.000$. The total variance explanation rate of these two factors was $75.03 \%$.

The reliability of the LIPT was calculated with Cronbach's Alpha coefficients as depicted in Table 1 and Table 2. These coefficients are sufficiently high (Hair et al., 1998).

Table 1: Reliability Coefficients for Mobbing Behaviour Exercised by Superiors and Peers

\begin{tabular}{lcc}
\hline \multicolumn{1}{c}{ Dimensions } & Superiors & Peers \\
\hline $\begin{array}{l}\text { Mobbing directed at preventing } \\
\text { the person from communicating } \\
\text { with others and asserting } \\
\text { oneself }\end{array}$ & 0.80 & 0.89 \\
\hline $\begin{array}{l}\text { Mobbing directed at social } \\
\text { relationships }\end{array}$ & 0.81 & 0.87 \\
\hline $\begin{array}{l}\text { Mobbing directed at the } \\
\text { reputation of the person }\end{array}$ & 0.79 & 0.84 \\
\hline $\begin{array}{l}\text { Mobbing directed at the quality } \\
\text { of life and career status of the } \\
\text { person }\end{array}$ & 0.81 & 0.90 \\
\hline $\begin{array}{l}\text { Mobbing through rumours, } \\
\text { criticism, rejection and unfair } \\
\text { evaluations }\end{array}$ & 0.91 & 0.90 \\
\hline
\end{tabular}

Table 2: Reliability Coefficients for Mobbing Behaviour Exercised by Subordinates

\begin{tabular}{lc}
\hline \multicolumn{1}{c}{ Dimensions } & Subordinates \\
\hline Mobbing directed at work & 0.97 \\
\hline Mobbing directed at personality & 0.95 \\
\hline
\end{tabular}

Job Satisfaction: The job satisfaction levels of respondents were measured by the 20 item reduced version of the original 100 item Minnesota Satisfaction Questionnaire-MSQ developed by Weiss, Davis, England and Lofquistin in 1967 (www.uni.edu, accessed 04.01.2008). Two items of the scale measure general satisfaction, twelve measure intrinsic satisfaction and six measure extrinsic satisfaction (Hancer and George, 2003; Toker, 2007). Each item was rated on five-point Likert type scale ranging from $1=$ not satisfied at all to $5=$ very satisfied. The internal consistency realiability test resulted in Cronbach Alpha value 0,96.

Turnover Intention: Turnover intention of respondents was measured by the 3 item turnover intention subscale taken from the Michigan Organizational Assessment Questionnaire developed by Cammann et al. in 1979. Each item was rated on a five-point Likert type scale ranging from $1=$ don't agree at all to $5=$ totally agree. The internal consistency realiability test resulted in Cronbach Alpha value 0,88.

\subsection{Findings}

\subsubsection{Demographic Findings}

$41.3 \%$ of respondents in the sample were in the age bracket $20-30,37.7 \%$ between $31-40,17.8 \%$ between $41-50$ and 3.2\% were 51 and above. 33.6\% of respondents were women, the rest $(66.4 \%)$ were men. Education level above high school (11 years) was a prerequisite for being included in the sample. For this reason $24.7 \%$ of the respondents had high school (lycee) or vocational high school education, $27.1 \%$ had 2 year higher education or vocational school education, $42.1 \%$ were graduates of bachelor programs and $6.1 \%$ had graduate degrees.

\subsubsection{Findings about Mobbing}

The highest rate of mobbing was exercised by peers, followed by superiors, that from subordinates remaining quite low. The percentages of $25.3 \%$ for mobbing exercised by superiors, $29.3 \%$ by peers and $1.6 \%$ by subordinates, add up to a considerable proportion (56.2\%) when evaluated in total. In the respondent group 46 employees had no subordinates, and the prevalence of mobbing from subordinates was calculated for 202 respondents. The relationships between the dimensions of mobbing exercised by 
superiors, peers and subordinates were examined by Pearson correlation test. The highest correlation $(r=0,858)$ was found between the dimensions of mobbing exercised by superiors and peers through rumours, criticism, rejection and unfair evaluations.

\subsubsection{Findings about Perceived Causes of Mobbing}

Table 3 summarizes the findings of the frequency analysis on the perceived causes of mobbing. It can be observed that the first group of perceived causes of mobbing is related with organizational factors $(53.3 \%)$, the second with the perpetrators (17.6\%), the third with social factors (15.1\%) and the fourth with the victims. "Imbalances in delegation of authority" was found to be the most important organizational factor giving rise to mobbing. Among the factors related with the perpetrator, fear of losing job, position or power resumes priority. And "envy and interpersonal rivalry" was the prime social factor leading to mobbing. Among the factors related with the victim, "superiority of talents and performance" was perceived as a cause of mobbing with the highest frequency.

Table 3: Perceived Causes of Mobbing

\begin{tabular}{lc}
\hline Causes & (\%) \\
\hline Organizational factors & $\mathbf{5 3 . 3}$ \\
\hline Imbalances in delegation of authority & 12.1 \\
\hline Excessive stress in work environment & 10.0 \\
\hline Excessive work load & 8.6 \\
\hline Weaknesses and uncertainties related with & 8.5 \\
management & 8.3 \\
\hline Gaps in corporate communication network & 5.8 \\
\hline Monotony of work & $\mathbf{1 7 . 6}$ \\
\hline Factors related with perpetrators & 7.0 \\
\hline Fear of losing job, position or power & 6.4 \\
\hline $\begin{array}{l}\text { Personality disorder (aggression, animosity, } \\
\text { egoism, cowardness etc.) }\end{array}$ & 4.2 \\
\hline $\begin{array}{l}\text { Prejudices with regard to age, gender or } \\
\text { education level of the victim }\end{array}$ & $\mathbf{1 5 . 1}$ \\
\hline Social factors & 9.4 \\
\hline Envy and interpersonal rivalry & 5.7 \\
\hline $\begin{array}{l}\text { Widespread disposition to scapegoat and } \\
\text { intimidate someone }\end{array}$ & 1.5 \\
\hline Factors related with victims & $\mathbf{1 3 . 4}$ \\
\hline Superiority in talents and performance & 5.4 \\
\hline $\begin{array}{l}\text { Strong personality traits (reliability, honesty) and } \\
\text { self-confidence }\end{array}$ & 5.4 \\
\hline Private life, religion or political view \\
\hline
\end{tabular}

4.3.4. Relationships between Perceived Causes and Dimensions of Mobbing

To test the first hypothesis $\mathrm{H} 1$ the relationships between the perceived causes and dimensions of mobbing were examined by t-test. The fear of the perpetrator to lose his/her job, position or power was found to be effective on all dimensions of mobbing exercised by superiors $\left(p^{*}<0.05, p^{* *}<0.01\right)$. The other perceived causes of mobbing did not display any significant effect on the same dimensions. The weaknesses and uncertainties emanating from management were found to be effective on all dimensions of mobbing exercised by peers $\left(p^{*}<0.05\right.$, $\left.p^{* *}<0.01\right)$. The other perceived causes of mobbing did not display any significant effect on the same dimensions. Excessive work load and gaps in the corporate communication networks had a significant effect on all dimensions of mobbing exercised by subordinates, $\left(p^{*}<0.05, p^{* *}<0.01\right)$. Taken together, it can be concluded that hypothesis $\mathrm{H} 1$ was partially supported.

\subsubsection{Relationships between the Dimensions of Mobbing and Job Satisfaction}

Table 4 summarizes the results of the regression analysis for the effects of three sources of mobbing (superiors, peers, subordinates) on the dependent variable job satisfaction. The results of the model developed for superiors have confirmed that three predictors (mobbing directed at preventing the personfromcommunicating withothersandasserting oneself, mobbing directed at social relationships, and mobbing through rumours, criticism, rejection and unfair evaluations) are significantly related to job satisfaction $\left(R^{2}=0.319, p<0.01\right)$. Mobbing exercised by superiors explains $32 \%$ of job satisfaction. Mobbing by superiors directed at preventing the person from communicating with others and asserting oneself has the greatest impact on job satisfaction ( $\beta=$ -0.383), while mobbing directed at the reputation of the person, and mobbing directed at the quality of life and career status of the person has no effect. $\mathrm{H}_{2 a}$ was partially supported.

The analysis on the impact of being exposed to mobbing from peers on job satisfaction showed that only mobbing directed at preventing the person from communicating with others and asserting oneself, and mobbing directed at social relations affected job satisfaction. Mobbing directed at social relations from peers had a greater impact ( $\beta=-0.299)$. Other three mobbing dimensions exercised by peers had no effect on the dependent variable (see Table 4). Therefore $\mathrm{H}_{2 b}$ proposing negative relationship between the dimensions of mobbing from peers and job satisfaction was partially supported. The regression analysis demonstrated that mobbing exercised by subordinates also lowered the job satisfaction of employees in the agricultural industry. As can be seen in Table 4, the $\mathrm{R}^{2}$ coefficient was 
Table 4: The Effects of Mobbing on Job Satisfaction

\begin{tabular}{|c|c|c|c|c|}
\hline & & Beta & $t$ value & $p$ value \\
\hline \multicolumn{5}{|l|}{ Mobbing exercised by superiors } \\
\hline 1st dimension (communication) & & $-0,383$ & $-4,95$ & $0,000 * *$ \\
\hline 2nd dimension (social relations) & & $-0,180$ & $-2,51$ & $0,013^{*}$ \\
\hline 3rd dimension (reputation) & & 0,122 & 1,80 & 0,072 \\
\hline 4th dimension (career status) & & 0,126 & 1,46 & 0,145 \\
\hline 5th dimension (rumour etc.) & & $-0,236$ & $-2,53$ & $0,012^{\star}$ \\
\hline$R^{2}=0,319$ & $F=22,634$ & \multicolumn{2}{|c|}{$p=0,000$} & \\
\hline \multicolumn{5}{|l|}{ Mobbing exercised by peers } \\
\hline 1st dimension (communication) & & $-0,328$ & $-2,64$ & $0,009 * *$ \\
\hline 2nd dimension (social relations) & & $-0,299$ & $-3,14$ & $0,002^{\star *}$ \\
\hline 3rd dimension (reputation) & & $-0,033$ & $-0,31$ & 0,751 \\
\hline 4th dimension (career status) & & 0,100 & 0,95 & 0,339 \\
\hline 5th dimension (rumour etc.) & & 0,011 & 0,08 & 0,931 \\
\hline$R^{2}=0,280$ & $F=18,826$ & \multicolumn{2}{|c|}{$p=0,000$} & \\
\hline \multicolumn{5}{|l|}{ Mobbing exercised by subordinates } \\
\hline 1st dimension (directed at work) & & 0,492 & 4,58 & $0,000 * *$ \\
\hline 2nd dimension (directed at personality) & & $-0,550$ & $-5,12$ & 0,000 ** \\
\hline$R^{2}=0,098$ & $F=13,325$ & \multicolumn{2}{|c|}{$p=0,000$} & \\
\hline
\end{tabular}

Dependent Variable: Job Satisfaction; Significance Level: $p^{\star}<0.05, p^{\star \star}<0.01$

low but significant. Job satisfaction of employees is affected more by the mobbing directed at personality by subordinates $(\beta=-0.550)$. Therefore $\mathrm{H}_{2 c}$ proposing that there is a negative relationship between the dimensions of mobbing exercised by subordinates and job satisfaction was accepted.

\subsubsection{Relationships between the Dimensions of Mobbing and Turnover Intention}

Multiple regression analysis was conducted to determine the impact of dimensions of mobbing

Table 5: The Effects of Mobbing on Turnover Intention

\begin{tabular}{|c|c|c|c|}
\hline & Beta & $\begin{array}{c}\mathrm{t} \\
\text { value }\end{array}$ & $p$ value \\
\hline \multicolumn{4}{|l|}{$\begin{array}{l}\text { Mobbing exercised by } \\
\text { superiors }\end{array}$} \\
\hline 1st dimension (communication) & 0,126 & 1,44 & 0,149 \\
\hline 2nd dimension (social relatio & 0,223 & 2,76 & $0,006^{\star *}$ \\
\hline 3rd dimension (reputation) & $-0,048$ & $-0,63$ & 0,526 \\
\hline 4th dimension (career status) & $-0,012$ & $-0,12$ & 0,904 \\
\hline 5th dimension (rumour etc.) & 0,112 & 1,06 & 0,288 \\
\hline $\mathrm{R}^{2}=0,137$ & $\mathrm{~F}=7,70$ & & $p=0,000$ \\
\hline \multicolumn{4}{|l|}{ Mobbing exercised by peers } \\
\hline 1st dimension (communication & 0,118 & 0,84 & 0,400 \\
\hline 2nd d & 0,263 & 2,45 & $0,015^{\star}$ \\
\hline (reputation) & $-0,042$ & $-0,35$ & 0,721 \\
\hline 4th dimension (career status) & $-0,040$ & $-0,34$ & 0,732 \\
\hline 5th dimension (rumour etc.) & $-0,016$ & $-0,10$ & 0,913 \\
\hline$R^{2}=0,083$ & $F=4,36$ & & $p=0,001$ \\
\hline \multicolumn{4}{|l|}{$\begin{array}{l}\text { Mobbing exercised by } \\
\text { subordinates }\end{array}$} \\
\hline 1st dimension (directed & $-0,314$ & $-2,82$ & $0,005^{\star *}$ \\
\hline $\begin{array}{l}\text { 2nd dimension (directed at } \\
\text { personality) }\end{array}$ & 0,281 & 2,52 & $0,012^{*}$ \\
\hline$R^{2}=0,032$ & $F=4,03$ & & $p=0,019$ \\
\hline
\end{tabular}

Dependent Variable: Turnover Intention; Significance Level: $\mathrm{p}^{*}<0.05, \mathrm{p}^{* *}<0.01$ on turnover intention. It can be seen in Table 5 that mobbing directed at social relations by superiors and peers were effective on turnover intention, the other dimensions had no impact. Therefore hypotheses $\mathrm{H} 3 \mathrm{a}$ and $\mathrm{H}_{3 \mathrm{~b}}$ were partially supported, but hypothesis $\mathrm{H} 3 \mathrm{c}$ proposing a positive relationship between dimensions of mobbing exercised by subordinates and turnover intention was accepted. The low value of $R^{2}$ in the regression analysis indicates that there are other factors that have an impact on the turnover intention.

\subsubsection{Findings on the Impact of Job Satisfaction on Turnover Intention}

Simple regression analysis was conducted to determine the relation between job satisfaction and turnover intention.

Table 6 shows that job satisfaction is effective on turnover intention and there is a negative relationship between these variables. Therefore hypothesis $\mathrm{H}_{4}$ was supported. The $\mathrm{R}^{2}$ coefficient shows that job satisfaction explains turnover intention by approximately $24 \%$ at a significance level of 0.01 .

Table 6: Impact of Job Satisfaction on Turnover Intention

\begin{tabular}{cccc}
\hline & Beta & t value & p value \\
\hline Job satisfaction & $-0,491$ & $-8,82$ & $0,000^{\star *}$ \\
$R^{2}=0,241$ & $F=77,942$ & & $p=0,000$
\end{tabular}

Dependent Variable: Turnover Intention; Significance Level: $\mathrm{p}^{*}<0.05, \mathrm{p}^{* *}<0.01$ 


\section{DISCUSSION}

Figure 1 depicts the structure of the research model resulting from the findings of the study which need to be discussed with reference to previous studies and contextual factors.

One of the major findings of this study was that, more than half (56.2\%) of the respondents had been exposed to mobbing during the previous year for at least six months. This finding is comparable to the findings of a study conducted in England, where $53 \%$ of employees were found to have been exposed to mobbing, and $78 \%$ declared to have witnessed mobbing (Chappel and Di Martino, 1998:6). In another study covering member states of the EU (TInaz, 2006: 2), it was estimated that at least 12 million people corresponding to $8 \%$ of total work force had been exposed to some kind of mobbing. On country basis, the rates of being exposed to mobbing was $16 \%$ of workforce in Britain, 10\% in Sweden, 9\% in France and Finland, $8 \%$ in Ireland and Germany, and $4 \%$ in Italy. The prevalence rate of mobbing in Turkey estimated by Dikmen (2005: 48) was $48 \%$. Similarly Aytaç et al. (2005: 335) found in their study on 877 white collar public health, education and security employees in Turkey that $55.1 \%$ had been exposed to one or several forms of mobbing during previous year, and $47.4 \%$ declared having witnessed such behavior. Even if the measurement techniques of these various studies may differ, the prevalence of mobbing in Turkey seems to be much higher than the other European countries (Mikkelsen and Einarsen, 2001; Özarallı and Torun, 2007). This may be explained by the relatively late recognition of the criminal aspect of this phenomenon in Turkey, and the inadequacy of legal measures that have been put into effect to prevent

Figure 1: The Resultant Model of the Research

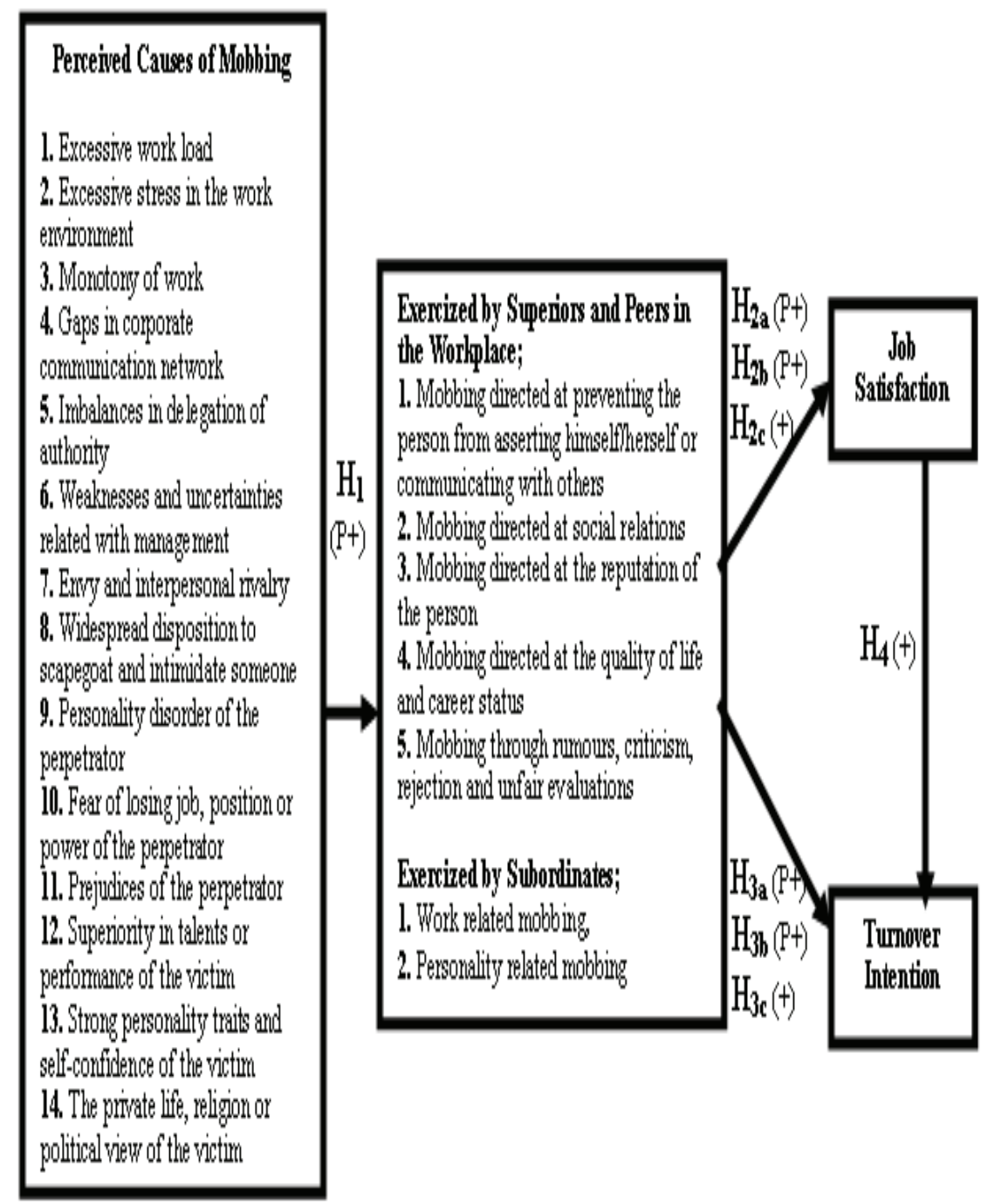

+ : Hypothesis completely supported, P+ : Hypothesis partially supported 
it. Academic interest in this topic is also quite recent (Bozbel and Palaz, 2007; Tutar, 2004). In the Turkish legal system, there is no provision directly dealing with mobbing, but some articles of the Constitution, the Code of Work Law and the Law of Obligations regulating work life can be used to handle such issues (Aytolun, 2009: 1). The Code of Criminal Law, the Code of Civil Law and the European Agreement on Human Rights are also employed in dealing with such conflict situations. The difficulty of proving the imperceptible aggression involved in mobbing reduces the strength of the means of fighting against it in the workplace, in the absence of properly defined legal provisions, like those in Sweden and the other EU countries. In such cases, rather than going to the court most of the victims quit job.

Another important finding of this study was that respondents had been exposed to mobbing most frequently by their peers (29.3\%), followed by superiors $(25.3 \%)$ and then the subordinates, but at a very low rate (1.6\%). Other studies conducted in Turkey found similar results (Dikmen, 2005; Ergin, 2000). These findings are in conformance with the results of some studies conducted in Scandinavian countries and Australia (Kök, 2006; Bilgel et al. 2006). However, many studies from Europe indicate that the perpetrators are generally superiors in power positions (Jacobshagen, 2004; Rayner, 2002). The study by Salin (2001: 435) showed that, though all employees may be subjected to mobbing, those in the lower levels of the hierarchy are more likely to be exposed to such treatment, and the perpetrators are generally the supervisors. In the present study, though the difference with peers is not so big (4\%), the superiors ranked the second in frequency of mobbing. Considering the paternalist management culture in Turkey, the high prevalence of mobbing in this study (25.3\%) from superiors may be explained with the fact that in patriarchial societies the relationship between superior and subordinate resembles that between parent and child. The superior is presented as a protective, disciplinarian and respected father figure whose authority is never questioned. This father figure assumes the power to reward or punish the subordinate as he/she considers appropriate. Organizational factors that foster the fear of the superior to lose his/her job, position or power, or interpersonal envy and rivalry, may be likewise effective.

Similarly, the minimal level (1.6\%) of mobbing from subordinates may be explained by the high power distance feature of the collectivist culture in Turkey which restrains employees from criticising their superiors (Sümer, 2000: 79) and keeps them from falling into conflict with them (Özen, 1996: 18). Ergin (2000: 248) emphasized in his study that in the high power distance Turkish culture employees very seldom confronted their superiors, and vertical conflicts were not very frequent. On the other hand, the proximity of Turkish culture to low synergy societies was indicated as an explanation for the high prevalence of destructive rivalry and envy among peers, the tendency to win at the expense of the other's absolute loss, and the consequent mobbing behavior directed at peers (Aycan and Kanungo, 2000; Sargut, 2001).

The frequency analysis on fourteen items related with the perceived causes of mobbing indicated organizational factors as the foremost group of perceived causes, while the factors related with perpetrators took the second, the social factors the third, and the factors related with victims the fourth rank. These findings are in conformance with those of Zapf et al. (1996: 215) who also found organizational factors as the most important causes of mobbing. However, other empirical studies on causes of mobbing carried on three categories defined by Leymann (1996: 177-178) (factors related with the type of organization, inadequacy of conflict management and personality of the victim) have generally focused on the personality of the victim and psychosocial factors (Einarsen, 1999: 20). The findings of the present study do not conform with the findings of those studies, but they are quite similar with the findings of another study conducted by Kök (2006: 441-444) on 300 bank employees in Turkey, which concluded that the major causes of mobbing are organizational factors, followed by social factors. These results indicate that for several reasons the organizational factors play the major role in fostering a workplace suitable for mobbing in the Turkish worklife. For SME's like those in the present study, low formalization and high uncertainty in the organization structure may be conducive to some social and personal causes for mobbing, like fear of losing job, position or power, envy and rivalry among employees. And for bureaucratic organizations like banks, organizational causes like excessive work load and stress, and/or monotony of work may likewise lead to mobbing behavior. The findings of this study carry important practical implications for HRM.

Other important findings of this study regarding the relationships between perceived causes and dimensions of mobbing were:

(i) The fear of the perpetrator to lose his/her job, position or power was found to be effective on all dimensions of mobbing exercised by superiors. The other perceived causes of mobbing did not display any significant effect on the same dimensions. 
(ii) The weaknesses and uncertainties emanating from management were found to be effective on all dimensions of mobbing exercised by peers. The other perceived causes of mobbing did not display any significant effect on the same dimensions.

(iii) Excessive work load and gaps in the corporate communication networks had a significant effect on all dimensions of mobbing exercised by subordinates.

The multiple regression analysis carried on the relationships between the dimensions of mobbing exercised by superiors and job satisfaction indicated that mobbing directed at preventing the person from communicating with others and asserting oneself, mobbing directed at social relationships, and mobbing through rumours, criticism, rejection and unfair evaluations lowers the job satisfaction of employees. The other two dimensions had no effect on job satisfaction. As to mobbing from peers, it was the mistreatment directed at preventing the person from communicating with others and asserting oneself, and mobbing directed at social relationships that lowered job satisfaction of employees. The other three dimensions, had no effect on job satisfaction. The important point to be emphasized is that, there is a negative relationship between job satisfaction and mobbing behavior directed at interpersonal communication and social relations by superiors and peers. This result can be explained with the dominance of collectivist culture giving rise to high need for social belonging in Turkish society (Sargut, 2001; Wasti, 2002). In collectivist cultures where interpersonal relations are valued highly, positive relationships in organizations elevate morale, motivation and satisfaction (Restubog and Bordia, 2006: 577-578). The absence of correspondence between job satisfaction and the other dimensions of mobbing can also be explained by the impact of dominant cultural traits on the mobbing process (Tınaz, 2006: 151). As to the correspondence between dimensions of mobbing from subordinates and job satisfaction, a negative relationship was found. The finding of this study that mobbing lowers job satisfaction is in conformance with the results of other studies conducted on the same topic (Salin, 2003: 1213).

The analyses also demonstrated that being subjected to mobbing directed at social relations by superiors and peers leads to turnover intention, whereas the other dimensions have no effect. On the other hand, positive relationship was found between turnover intention and both dimensions of mobbing by the subordinates. The overall results are in conformance with the findings of other studies which demonstrated that mobbing causes turnover intention (Moayed et al., 2006; Özarallı and Torun, 2007).

Analysis of the relationship between job satisfaction and turnover intention indicated that job satisfaction had a negative correspondence with turnover intention. This is in conformance with a number of studies which concluded that low job satisfaction led to turnover intention (Mor Barak et al., 2001: 629). The job satisfaction and turnover findings of the study were quite complementary. $57.2 \%$ of the respondents were satisfied with their work; $40 \%$ indicated that they were going to look for another job during next year, and $44.3 \%$ declared turnover intention. It can be predicted that those who are not satisfied with their jobs will look for other jobs the coming year. Previous research exploring if job satisfaction is a variable that determines work attitudes like turnover and absenteeism had generally concluded that turnover intention was low when job satisfaction was high (Weisberg and Kirschenbaum, 1991: 368). However, the socio-cultural and socio-economic structure of the society, unavailability of alternative job opportunities, and the financial and spiritual costs of looking for another job may prevent actualization of the turnover intention (Aycan and Kanungo, 2000; Restubog and Bordia, 2006). Kirschenbaum and Mano-Negrin (1999: 1233) have emphasized that turnover intention is not caused only by organizational factors; the local labour market, geographical constraints, the traits of work and the organization may influence the process. In this context, it would be useful to remember that the global financial crisis which started in summer of 2007 in the U.S. spread all over the world and gave rise to destructive effects also in Turkish economy, lowering growth rate to minus levels and increasing unemployment in the country (Togan, 2009: 7) to $16.1 \%$ as of February 2009 (Çolak, 2009: 66). This may explain why turnover intention cannot convert into actual turnover for many people.

\section{CONCLUSION}

As explained above, findings of the study demonstrated that more than half of the respondents (56.2\%) had been subjected to some kind of mobbing during the previous year, and for at least six months duration, mostly from peers and superiors, and generally due to organizational factors. Victims had lower levels of job satisfaction and most of them intended to leave the job. This level of prevalence is considerably higher than those observed in Europe, though exact comparison is difficult due to probable differences in research methodologies. 
As an explanation, the relative inadequacy of direct legal provisions aimed at providing protection to the victims can be indicated. Awareness and handling of mobbing issues is quite recent in Turkey, and some development is expected in the near future, in the framework of the accession negotiations with the EU.

Besides these legal factors, the research findings also indicated the importance of cultural and organizational context on the relations between the perceived causes and dimensions of mobbing, and organizational consequences like job satisfaction and turnover intention. It was especially the mobbing behavior directed at interpersonal communication and social relations exercised by superiors and peers that had the greatest negative effect on job satisfaction. The findings also demonstrated that being subjected to mobbing directed at social relations by superiors and peers leads to turnover intention, whereas the other dimensions have no effect. This result can be explained by the collectivist feature of Turkish culture that aggravates the need for social belonging. The high prevalence of mobbing from superiors (25.3\%) and low prevalence from subordinates $(1.6 \%)$ can be likewise interpreted in the light of the high-power distance, patriarchial culture prevailing in Turkish business life that fosters authoritarian behavior from superiors and limits offensive behavior from subordinates. Therefore it can be expected that national cultures are effective on the formation, development and outcome phases of the mobbing process.

Another important conclusion to be drawn from this study is that organizational factors play the major role in fostering a workplace suitable for mobbing in the Turkish worklife. The fear of the perpetrator to lose his/her job, position or power was found to be effective on all dimensions of mobbing exercised by superiors. The weaknesses and uncertainties emanating from management were found to be effective on all dimensions of mobbing exercised by peers, and excessive work load and gaps in the corporate communication networks had a significant effect on all dimensions of mobbing exercised by subordinates. For SME's like those in the present study, low formalization and high uncertainty in the organization structure may be expected to trigger some social and personal causes for mobbing. The findings of this study carry important practical implications for HRM.

This present study confirmed that, mobbing is a phenomenon that is widely confronted, but to a large extent overlooked process in organizational settings, generally not subjected to any diagnosis and treatment in Turkey. As the findings of the present research demonstrated, mobbing practices damage organizational relations, lower job satisfaction and give rise to increased turnover intentions. Therefore it is very important to build up individual and organizational awarenessconcerningmobbing byinvestigating itfrom different perpectives of organizational behavior and HRM. Though it would not be possible to completely eradicate mobbing in organizations where people are in constant interaction, organizational practices aiming at trust, justice and commitment have been usefully employed in dealing with mobbing. Therefore exploration of the relations between mobbing and (i) organizational commitment, justice, trust; (ii) culture; (iii) empowerment; (iv) personality differences, and (v) cultural differences are recommended for future research.

The limitations of the present study should be considered before generalizing the results. The study was conducted only in seven SME's in the agricultural sector of Antalya and on employees graduated from high school or above. The mediation of the personnel or human resources or administrative-financial managers to the distribution of questionnaires may be also taken as a limitation. Another limitation was the use of the short version of the MSQ to facilitate data collection.

\section{REFERENCES}

Antalya Büyükşehir Belediyesi (2009)

http: / / www.antalya.com.tr/tr/ekonomi/tarim. cfm?tanitimId=905, (11.08.2009).

Aycan, Z. and Kanungo, R.N. (2000) "Toplumsal Kültürün Kurumsal Kültür ve İnsan Kaynakları Uygulamaları Üzerine Etkileri" (Social Culture's Effects on Institutional Culture and Human Resources Practices), Aycan Z. (ed.) Akademisyenler ve Profesyoneller Bakı̧ Açısıyla Türkiye'de Yönetim, Liderlik ve Insan Kaynakları Uygulamaları, Ankara, Türk Psikologlar Derneği Yayınları, 21: 25-53.

Aytaç, S., Bayram, N. and Bilgel, N. (2005) "Çalışma Yaşamında
Yeni Bir Baskı Aracı: Mobbing” (A New Pressure Instrument in Working Life: Mobbing), İstanbul, 13. Ulusal Yönetim ve Organizasyon Kongresi Bildiriler Kitabı: 333-337.

Aytolun, Z. (2009) “Meğer Mobbing’e Uğramışım!” (Although I Have Been Mobbed), Cumburiyet PAZAR, 23(1206/3rd May): $1-3$.

Baykal, A.N. (2005) Yutucu Rekabet: Kanuni Devrindeki Mobbing'den Günümüze (Absortive Competition: From the Mobbing of Kanuni's Period to Present), İstanbul, Sistem Yayıncilık.

Bilgel, N., Aytaç, S. and Bayram, N. (2006) "Bullying in Turkish 
White-Collar Workers", Occupational Medicine, 56: 226-231.

Bozbel, S. and Palaz, S. (2007) "İşyerinde Psikolojik Taciz (Mobbing) ve Hukuki Sonuçları” (Mobbing and Its Legal Consequences), TISK Akademi Dergisi, 1: 66-81.

Cammann, C., Fichman, M., Jenkins, D. and Klesh, J. (1979) "The Michigan Organizational Assessment Questionnaire", Unpublished Manuscript, University of Michigan, Ann Arbor.

Chappel, D. and Di Martino, V. (1998) "Violence at Work" (Workplace Violence: A New Global Problem), World of Work The Magazine of the International Labor Office (ILO) Report, 26.

Clarke, J. (2002) Maymuncuk: İsyerinde İletişim ve Politika (Master Key: Communication and Policy in the Workplace), Dicleli Z. (trans.) İstanbul, MESS Yayınları.

Çekmecelioğlu, H. (2006) "İş Tatmini ve Örgütsel Bağlllık Tutumlarının İşten Ayrılma Niyeti ve Verimlilik Üzerindeki Etkilerinin Değerlendirilmesi: Bir Araştırma" (Evaluation of Effect of Work Satisfaction and Organizational Commitment on Intention to Leave and Productivity: A Research), $\dot{I}_{s ̧}$, Güç Endüstri İliskileri ve Insan Kaynakları Dergisi, 8(2): 153-168.

Çobanoğlu, Ş. (2005) Mobbing: İsyerinde Duygusal Saldır ve Mücadele Yöntemleri (Mobbing: Emotional Attack in the Workplace and Coping Strategies with Mobbing), İstanbul, Timaş Yayınları.

Çolak, Ö.F. (2009) "2008 Krizinin 1929 Krizi ile Benzerlikleri Üzerine Bir Analiz" (An Analysis of the Similarities between 2008 and 1929 Crisis), TISK Akademi Dergisi, 4(Özel SayıII): 50-69.

Davenport, N., Schwartz, R.D. and Elliott, G.P. (2003) Mobbing, Önertoy O.C. (trans.) İstanbul, Sistem Yayıncilık.

Dikmen, A. (2005) "Workplace Bullying/Mobbing and Its Effects on Intention to Leave the Organization", Marmara Universitesi Sosyal Bilimler Enstitüsü İsletme Anabilim Dalı Örgütsel Davranı̧̧ Bilim Dalı Yüksek Lisans Tezi, İstanbul.

Duffy, M. and Sperry, L. (2007) "Workplace Mobbing: Individual and Family Health Consequences", The Family Journal, 15: 398-404.

Djurkovic, N., McCormack, D. and Casimir, G. (2004) "The Physical and Psychological Effects of Workplace Bullying and Their Relationship to Intention to Leave: A Test of the Psychosomatic and Disability Hypotheses", International Journal of Organization Theory and Behavior, 7(4): 469-497.

Einarsen, S. (2000) "Harassment and Bullying at Work: A Review of the Scandinavian Approach", Aggression and Violent Behavior, 5(4): 379-401.

Einarsen, S. (1999) "The Nature and Causes of Bullying at Work", International Journal of Manpower, 20(1-2): 16-27.

Einarsen, S., Raknes, B.I. and Matthiesen, S.B. (1994) "Bullying and Harassment at Work and Their Relationships to Work Environment Quality: An Exploratory Study", European Work and Organizational Psychologist, 4(4): 381-401.

Ergin, C. (2000) "Türkiye'deki Örgütlerde Çatısmaların Çözümlenmesine İlişkin Çalışmalar” (Studies about Conflict Solution in the Organizations in Turkey), Aycan Z. (ed.) Akademisyenler ve Profesyoneller Bakı̧s Açısıyla Türkiyéde
Yönetim, Liderlik ve İnsan Kaynaklar Uygulamalar, Ankara, Türk Psikologlar Derneği Yayınları, 21: 243-259.

Greenhaus, J.H., Allen, T.D. and Spector, P.E. (2006) "Health Consequences of Work-Family Conflict: The Dark Side of the Work-Family Interface", Research in Occupational Stress and Well Being, 5: 61-98.

Hair, J.F., Anderson, R.E., Tatham, R.L. and Black, W.C. (1998) Multivariate Data Analysis, New Jersey, Pearson Education.

Hancer, M. and George, R.T. (2003) "Job Satisfaction of Restaurant Employees: An Empirical Investigation Using The Minnesota Satisfaction Questionnaire”, Journal of Hospitality and Tourism Research, 27(1): 85-100.

Hubert, A.B. and Veldhoven, M.V. (2001) "Risk Sectors for Undesirable Behaviour and Mobbing", European Journal of Work and Organizational Psychology, 10(4): 415-424.

Hürriyet İK (2009) http://www.yenibiris.com/HurriyetIK/, (29.03.2009).

Hürriyet İK (2009) http://www.yenibiris.com/HurriyetIK/, (05.04.2009).

Jacobshagen, N. (2004) "Mobbing-Ein Langer, Zermürbender Prozess", Praxis - Schweiz Med Forum, 4: 873-878.

Kirschenbaum, A. and Mano-Negrin, R. (1999) "Underlying Labor Market Dimensions of 'Opportunities': The Case of Employee Turnover”, Human Relations, 52(10): 1233-1255.

Kök, S.B. (2006) "İş Yaşamında Psiko-Şiddet Sarmalı Olarak Yildirma Olgusu ve Nedenleri” (The Mobbing Phenomenon and Its Reasons as a Spiral of Psychological Violence in the Workplace), Erzurum, 14. Ulusal Yönetim ve Organizasyon Kongresi Bildiriler Kitabı: 433-448.

Kuvaas, B. (2006) "Performance Appraisal Satisfaction and Employee Outcomes: Mediating and Moderating Roles of Work Motivation", International Journal of Human Resource Management, 17(3): 504-522.

Lee, T.W., Mitchell, T.R., Sablynski, C.J., Burton, J.P. and Holtom, B.C. (2004) "The Effects of Job Embeddedness on Organizational Citizenship, Job Performance, Volitional Absences, and Voluntary Turnover", Academy of Management Journal, 47(5): 711-722.

Lee, D. (2000) "An Analysis of Workplace Bullying in the UK", Personnel Review, 29(5): 593-612.

Leymann, H. (1990) LIPT Questionnaire, http://www.leymann. se/deutsch/frame.html, (09.07.2007).

Leymann, H. (1996) “The Content and Development of Mobbing at Work", European Journal of Work and Organizational Psychology, 5(2): 165-184.

Leymann, H. (1993) Mobbing Psychoterror am Arbeitzplatz Und Wie Man Sich Dagegen Wehren Kann, Hamburg, Rowohlt Taschenbuch Verlag GmbH.

Mikkelsen, E.G. and Einarsen, S. (2001) "Bullying in Danish Work-Life: Prevalence and Health Correlates", European Journal of Work and Organizational Psychology, 10(4): 393413.

Moayed, F.A., Daraiseh, N., Shell, R. and Salem, S. (2006) "Workplace Bullying: A Systematic Review of Risk Factors 
and Outcomes", Theoretical Issues in Ergonomics Science, 7(3): 311-327.

Mor Barak, M.E., Nissly, J.A. and Levin, A. (2001) "Antecedents to Retention and Turnover among Child Welfare, Social Work, and Other Human Service Employees: What Can We Learn from Past Research? A Review and Metanalysis", Social Service Review, 75(4): 625-661.

Morrison, R.L. and Nolan, T. (2007) "Negative Relationships in the Workplace: A Qualitative Study", Qualitative Research in Accounting and Management, 4(3): 203-221.

Özarallı, N. and Torun, A. (2007) "Çalışanlara Uygulanan Zorbalığın Mağdurların Kişilik Özellikleri, Negatif Duygular ve İşten Ayrılma Niyetleriyle İlişkisi Üzerine Bir Araştırma” (A Research on Victims' Personality Characteristics, Negative Emotions and Turnover Intentions Relation with Bullying to Implement to Workers), Sakarya, 15. Ulusal Yönetim ve Organizasyon Kongresi Bildiriler Kitabı: 939-947.

Özen, Ş. (1996) Bürokratik Kültür 1: Yönetsel Değerlerin Toplumsal Temelleri (Bureaucratic Culture 1: Foundations of Social of Managerial Values), Ankara, Türkiye ve Orta Doğu Amme İdaresi Enstitüsü (TODAİ), 272.

Quine, L. (2001) "Workplace Bullying in Nurses", Journal of Health Psychology, 6(1): 73-84.

Rayner, C. (2002) "Round Two: Redefining Bullying at Work", Paper Presented as Part of a Joint Session-Workplace Abuse, Aggression, Bullying and Incivility: Conceptual Integration and Emprical Insights, American Academy of Management Meeting, CO, Denver.

Rayner, C. and Hoel, H. (1997) "A Summary Review of Literature Relating to Workplace Bullying", Journal of Community and Applied Social Psychology, 7: 181-191.

Restubog, S.L.D. and Bordia, P. (2006) "Workplace Familism and Psychological Contract Breach in the Philippines", Applied Psychology: An International Review, 55(4): 563-585.

Salin, D. (2003) "Ways of Explaining Workplace Bullying: A Review of Enabling, Motivating and Precipitating Structures and Processes in the Work Environment", Human Relations, 56(10): 1213-1232.

Salin, D. (2001) "Prevalence and Forms of Bullying among Business Professionals: A Comparison of Two Different Strategies for Measuring Bullying", European Journal of Work and Organizational Psychology, 10(4): 425-441.

Sargut, A.S. (2001) Kültürlerarası Farklılaşma ve Yönetim (Differentiation and Management between Cultures), Ankara, İmge Kitabevi Yayınları.

Schat, A.C.H. and Kelloway, E.K. (2000) "The Effects of Perceived Control on the Outcomes of Workplace Aggression and Violence", Journal of Occupational Health Psychology, 4: 386-402.
Seifert, T.A. and Umbach, P.D. (2008) "The Effects of Faculty Demographic Characteristics and Disciplinary Context on Dimensions of Job Satisfaction", Research in Higher Education, 49: 357-381.

Sümer, H.C. (2000): "Performans Değerlendirmesine Tarihsel Bir Bakış ve Kültürel Bir Yaklaşım” (A Historical View and Cultural Approach on Performance Rating), Aycan Z. (ed.) Akademisyenler ve Profesyoneller Bakış Açısıyla Türkiye'de Yönetim, Liderlik ve Insan Kaynakları Uygulamaları, Ankara, Türk Psikologlar Derneği Yayınları, 21: 57-90.

Thomas, M. (2005) "Bullying among Support Staff in a Higher Education Institution”, Health Education, 105(4): 273-288.

Tınaz, P. (2006) İsyerinde Psikolojik Taciz (Mobbing), İstanbul, Beta Basım Yayım Dağıtım A.Ş.

Togan, S. (2009) "Küresel Kriz ve Türkiye" (Global Financial Crisis and Turkey), TISK Akademi Dergisi, 4(Özel Sayı-II): 6-25.

Toker, B. (2007) "Demografik Değişkenlerin İş Tatminine Etkileri: İzmir'deki Beş ve Dört Yıldızlı Otellere Yönelik Bir Uygulama" (The Effects of Demographic Factors on Job Satisfaction: An Application on Five and Four Star Hotels In Izmir), Doğuş Üniversitesi Dergisi, 8(1): 92-107.

Tutar, H. (2004) İşY Yerinde Psikolojik Şiddet (Psychological Violence in the Workplace), Ankara, Barış Kitap Basım Yayın Dağıtım Ltd. Şti.

University of Northern IOWA (2008): http://www.uni.edu/ butlera/Courses/org/msq.htm, (04.01.2008).

Vandekerckhove, W. and Commers, M.S.R. (2003) "Downward Workplace Mobbing: A Sign of the Times?", Journal of Business Ethics, 45(1/2): 41-50.

Vartia, M. (1996) "The Sources of Bullying-Psychological Work Environment and Organizational Climate", European Journal of Work and Organizational Psychology, 5(2): 203-214.

Wasti, S.A. (2002) "Affective and Continuance Commitment to the Organization: Test of an Integrated Model in the Turkish Context", International Journal of Intercultural Relations, 26: 525-550.

Weisberg, J. and Kirschenbaum, A. (1991) "Employee Turnover Intentions: Implications From a National Sample", The International Journal of Human Resource Management, 2(3): 359-375.

Zapf, D. (1999) "Organisational, Work Group Related and Personal Causes of Mobbing/Bullying at Work", International Journal of Manpower, 20(1/2): 70-85.

Zapf, D., Knorz, C. and Kulla, M. (1996) "On the Relationship between Mobbing Factors, and Job Content, Social Work Environment, and Health Outcomes", European Journal of Work and Organizational Psychology, 5(2): 215-237. 